\title{
What Factors Affect to Curation Commerce Website Loyalty Intention: The Mediating Effects of Perceived Deception
}

\author{
DOI: 10.12776/QIP.V21I3.984
}

Sunghee Park, Jaehyeon Jun, Heejun Park

Received: 19 September 2017 Accepted: 23 October 2017 Published: 30 November 2017

\begin{abstract}
Purpose: As the importance of information quality has become prominent in the internet commerce, curation techniques are also stands out as well. Therefore, many services on e-commerce applied with curation techniques to satisfy their consumers. However, besides the fact that plenty of advantages from curation commerce, the growth of curation commerce websites have been slowdown. Thus, this paper is to investigate factors influencing curatiaxon commerce websites' consumer loyalty intentions for enhancing the competitiveness of curation commerce websites.
\end{abstract}

Methodology/Approach: This study sets independent variables regarding provider recommendation and consumer review simultaneously and verifies to see how each factors affect to consumer's loyalty intention through perceived deception and satisfaction in the curation commerce website. We applied structural equation model to verify the hypothesis and conduted a survey on consumer who had buying expriences in Korean curation commerce website.

Findings: The results of this study show what fators significantly affect to loyalty intention. Consumers on curation commerce mostly tend to be affected by other consumers' review and they only affected by presentation of product among provider recommedations. We conducted an important mediating effect of satisfaction between perceived deception and loyalty intention. Furthermore, because curation commerce is a relatively new concept, this attempt could form the basis for research on cuartion commerce.

Research Limitation/implication: This research only collected sample data form curation commerce websites users in Korea and because young consumers onsistute the majority of the respondednts, generalizing the findings to individuals of all ages and nations is difficult. 
Originality/Value of paper: This paper is the first study applying product recommendation and consumer review simultaneouly as an independent variable. These attempts enable to reflect more specific and practical behavior of consumers. Effect of satisfaction on loyalty and relationship between deception and loyalty are well documented in the offline and online retail context. This study expands and verifies estabilshed relationship among the variables on the lastest commerce website.

Category: Research paper

Keywords: loyalty; perceived deception; provider recommendation; consumer review; curation commerce

\section{INTRODUCTION}

The practical use of the Internet for commerce is continuously growing, and the number of online shopping use is tremendously increasing each year. However, unfortunately, deceptive information in the e-commerce market continues to increase. Consequently, the question arises regarding how to obtain the precise information that consumers need. One of the possible solution considered is "curation". Consumers obtain tremendous product/service information that can meet their demands in commerce. However, they cannot verify if this information is accurate and true. In this case, curation collects valuable and trustworthy information from the massive volume of related data and offers verified product/service information that matches consumers' needs (Tan, 2007). The usefulness of curation leads to its application in numerous fields. In South Korea, companies have developed and applied concpet of curation to commerce. However, the market has yet to reach the expected level. Therefore, many curation commerce websites face difficulties in achieving sustainability. To strengthen competitiveness of lastest e-commerce website, we focused on quality of information on e-commerce website. Because previous research has shown that the information on an e-commerce website and shared between provider and consumer is considered one of the most important aspects of enhancing the website's competitiveness and guaranteeing its sustainability (Klein, 1998; Lynch Jr and Ariely, 2000). In this research, we define provider recommendation (PR) content as the most important content that sellers give to consumers and define consumer review (CR) content as the most effective information content shared by consumers. We verify the characteristics of PR content and CR content that affect the consumer loyalty intention. Through this analysis of effects, we suggest a strategy to increase the competitiveness of a curation commerce website and to create actual purchase demand from consumers' potential demand. 


\section{THEORETICAL BACKGROUND}

\subsection{B2C Websites and Curation Commerce Website}

Many prior papers focus on reporting the status of B2C e-commerce websites (Ho, 1997; Dorčák, Štrach and Pollák, 2015), predicting future trends, and providing guidelines for managing B2C websites (Gogan, 1996; Morris and Hinrichs, 1996). Each B2C website had a different way to serve and sort the information on its products and services. The key characteristics of a B2C website are revealed along the lines of its design and content. To satisfy consumers and sell goods, B2C websites provide information in various ways and create diverse e-commerce markets. As an example of a recent e-commerce type, one B2C website adds a social network aspect. Social commerce refers to the use of e-commerce activities and transactions through a social media environment, in particular in social networks using Web 2.0 software. Thus, social commerce can be considered a subset of e-commerce that includes using social media to assist in user content contributions (Liang and Turban, 2011). New B2C websites such as social commerce, provide a variety of content and value that old websites cannot. Given the advent of various B2C websites that have new aspects and an increasing number of consumers using them, the amount of data stored electronically has become excessive. Moreover, accessible data on the Internet continue to grow at an enormous pace. This trend will not only continue but also accelerate in the future (Ramírez, 2011). As a result, the problem is how to search for the best choice among the enormous volume of information. Thus, search has been an essential tool for selecting suitable information (Brin, 1998). Providing accurate information in a better manner than search tools do has become necessary. In these states, a curation service, in many cases, can provide assured information that has been quality checked and is relevant to specific areas (Tan, 2007). Using these advantages, e-coomerce has recently begun to be applied to th concept of curation. Because this is the most advanced form of e-commerce, we set up curation commerce websites as subject of research.

\subsection{S-O-R Theory}

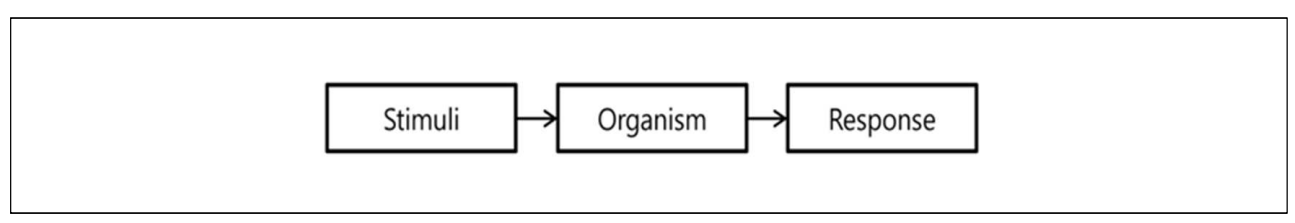

Figure 1 - Conceptual Framework

The research framework of this study is based on the S-O-R paradigm, which is generally used in studies in both the traditional and e-commerce marketing fields. Using this paradigm, prior studies verify a relationship between the store 
environment and consumer cognition. They indicate ambient factors, design factors, and social factors as a store environment that provides stimuli and defines merchandise and service quality as inferences that explain the organism. Lastly, they establish the store image to indicate cognition as a mean response (Baker, Grewal and Parasuraman, 1994). Additionally, Chang and Chen confirm the impact of cues in the online store environment on purchase intention using the S-O-R paradigm. They define website quality and brand as stimuli, assign trust and perceived risk as organism, and assign purchase intention as response (Chang and Chen, 2008). Considering prior research, the conceptualization of stimuli - explained as something that arouses or incites to action - has been used and accepted in the literature (Bagozzi, 1986). In a consumer decision-making context, the stimuli can be conceptualized as the external factors associated with a pending decision (Bagozzi, 1986). Thus, the stimuli are represented by various store atmosphere factors or website characteristics. Additionally, the stimuli are expected to influence a consumer's perceived feeling when shopping (Sherman, Mathur and Smith, 1997). In this research, we consider stimuli as variables related to the characteristics of the information content. Organism refers to the internal processes between the stimuli to the person's final actions, reactions, or responses. Note that the intervening structures consist of perceptual, physiological, feeling, and thinking activities (Bagozzi, 1986). Consistent with this definition, the emotional state is conceptualized as the organismic variable. In preceding studies, researchers have defined organism variables that have positive effects on consumer behavior. In this research, we focus on perceived deception as the organism. Bagozzi defines response as the outcome or final action or reaction of consumers, including psychological reactions such as attitudes and/or behavior (Bagozzi, 1986). Moreover, these attitudes and/or behavioral reactions are affected by a consumer's emotional state. Thus, in this study, we set consumer satisfaction and consumer loyalty intentions as response variables.

\subsection{Perceived Deception}

In the traditional marketing field, deception is perceived as having special interest in the areas of advertising and personal retailing. In the context of marketing practices, deception is defined as unethical and unfair information to the deceived (Aditya, 2001). Preceding research in the retailing and personal selling context identifies deception as exaggerating product features and selling items using high-pressure selling techniques. Such research also implies that deceptive selling actions are found to decrease consumer satisfaction and trust (Ingram, Skinner and Taylor, 2005; Román and Ruiz, 2005). Additionally, few researchers concentrate on deception in e-commerce. One study conducted by Roman developed a scale to measure consumers' perceptions regarding the ethics of online retailers (CPEOR). His findings indicated that the CPEOR scale had four dimensions: security, privacy, non-deception, and fulfillment/reliability (Roman, 2007). Recently, Sergio Román represents the direct effect of perceived 
deception toward consumer satisfaction and consumer loyalty intentions in online retailing. He finds that perceived deception negatively affects consumer satisfaction and represents that consumer satisfaction positively affects consumer loyalty intentions. However, perceived deception has no effect on consumer loyalty intentions (Román, 2010).

\section{HYPOTEHSIS}

\subsection{Argument Strength}

Argument strength is referred as the quality of the received information (Cacioppo, et al., 1983) and is the extent to which people perceive the argument of a received message as convincing or valid in supporting an opinion. The previous studu verifies that argument strength directly affects the receiver's attitude in online environments (Cacioppo, Petty and Morris, 1983). If the received information is perceived as a valid argument, the receiver adopts a positive attitude toward the information and considers it credible. Conversely, if the received information is cognized as invalid, the receiver adopts a negative attitude toward the information and treats it as deceptive (Cheung, et al., 2009). Additionally, prior studies demonstrate the effect of argument strength on perceived value in both physical communication and computer-mediated communication contexts (Bunker, 1994; Nabi and Hendriks, 2003). According to prior studies, argument strength proves to be an important element that individuals use to evaluate incoming communications. Particularly in a curation website environment, providers and consumers communicate through arguments on the website. Therefore, most consumers primarily depend on provider and consumer opinions of products or services and judge the deception in online websites based on the argument strength of PR and CR.

H1a: PR argument strength has a negative effect on perceived deception.

H1b: CR argument strength has a negative effect on perceived deception.

\subsection{Sidedness}

Research in the marketing field has been interested in the attitudinal effects of one-sided vs. two-sided messages in word-of-mouth communications. The onesided message represents either the positive or the negative side of the product or service. In contrast, a two-sided message contains both positive and negative elements (Cho, 1995). Regarding the consumer's position, every product or service has its strengths and weaknesses. Receiving information on both strengths and weaknesses enhances the credibility and quality of that information. Hence, two-sided information tends to be perceived as more credible and reduces the deception in information (Smith and Hunt, 1978). Prior study proves that two-sided product information is more persuasive than only positive information (Allen, 1993). Previous research state that two-sided 
information reduces the information receiver's skepticism and deception; therefore, it may intensify the credibility of the information (Belch, 1981). Particularly, in a curation commerce website, the effect of information sidedness is addressed with more sensitivity. Products or services in a curation commerce website are mostly unfamiliar to consumers. Therefore, when consumers visit such websites, they depend completely on the provider's recommendations and consumers' reviews, along with their own experience, to evaluate the goods. Thus, PR and CR content that objectively use two-sided words reduce the deceptive nature of the website.

H2a: PR sidedness has a negative effect on perceived deception.

H2b: CR sidedness has a negative effect on perceived deception.

\subsection{Product Presentation}

In the marketing field, the visual presentation of goods may create an emotional response during purchases (Swinyard, 1993). For example, an appealing visual presentation of goods may accelerate consumers' intention to purchase (Then and DeLong, 1999). Thus, product displays at the store are directly related to sales. Particularly in e-commerce, this point is more important in providing adequate visual information to consumers because consumers should rely on what they have seen on screen when purchasing goods. Then and DeLong verified that visual presentation can provide product information that is known to affect consumer purchase intentions regarding online sales (Then and DeLong, 1999). Additionally, different aspects of previous research exist. If the visual information of goods is not attractive enough to make judgments regarding the goods, perceive risk or other negative cognitions increase, causing consumers to avoid purchasing the goods from the Internet (Park, Lennon and Stoel, 2005). In curation commerce, consumers are surely concerned about the product presentation of the provider. Moreover, consumers have recently also referred to other consumers' product presentation. Thus, a product presentation of high quality decreases the deception of the website.

H3a: PR product presentation has a negative effect on perceived deception.

H3b: CR product presentation has a negative effect on perceived deception.

\subsection{Perceived Deception}

To suggest the effect of deception on satisfaction, this study adopts the expectancy disconfirmation paradigm (Oliver and DeSarbo, 1988). This theory holds that consumers make comparisons between product expectations and performance that result in either acceptance or rejection. Consumers' expectations are satisfied when product performance exactly meets these expectations. In contrast, disconfirmation is the result of a discrepancy between expectations and performance. Positive disconfirmation occurs when product performance exceeds prior expectations, and negative disconfirmation occurs 
when performance does not meet expectations. Confirmation and positive disconfirmation are likely to lead to satisfaction, whereas negative disconfirmation cause dissatisfaction. Consumer expectations regarding the goods are highly dependent on the information content uploaded onto the website. An online information provider that implements deceptive techniques is more likely to exaggerate unrealistic expectations about the goods, which may result in negative disconfirmation in expectations and product performance and may lead to consumer dissatisfaction of the website. Prior research in ecommerce settings provides empirical evidence for the negative effect of deceptive feelings about a website on consumer satisfaction (Román, 2010). In this study, we expand the analysis to curation commerce settings.

H4: Perceived deception has a negative effect on consumer satisfaction.

Loyalty intentions can be adopted using equity theory (Adams, 1963). One study based on equity theory indicates that consumers often evaluate marketplace transactions by considering how equitably each group has contributed to an exchange in traditional commerce (Huppertz, Arenson and Evans, 1978). In particular, equity theory argues that if one group of consumers recognizes an unfair benefit, the disadvantaged group views the situation as inequitable and intends to achieve a balance or restore equilibrium. Therefore, if consumers perceive providers' attempts at deception, they feel inequitable, causing negative effects on loyalty intentions. Early research in offline retail settings links consumers' perceptions of deceptive practices to loyalty (Whalen, Pitts and Wong, 1991). Only a recent study verifies the relationship between perceived deception and loyalty intentions in online retail settings.

H5: Perceived deception has a negative effect on consumer loyalty intention.

\subsection{Consumer Satisfaction and Loyalty Intentions}

Prior research regarding consumer loyalty, Consumer satisfaction and the positive effect of satisfaction on loyalty has been well documented in the offline retail context (Ingram, Skinner and Taylor, 2005; Vykydal, Halfarová and Nenadál, 2013; Horváth and Michalkova, 2012). Recently, this relationship also has been verified in the online environment (Fassnacht and Köse, 2007; Román, 2010) and could be explained by the fact that consumers who are satisfied by high value goods are more likely to be loyal to the company. Therefore, they tend to purchase goods from that company in the future and behave in a manner that is beneficial to the company through writing positive CR, spreading positive wordof-mouth, and/or posting positive electronic word-of-mouse through social network services. Thus, we expect that satisfaction with an online retailer will increase loyalty intentions.

H6: Consumer satisfaction has a positive effect on consumer loyalty intentions. 


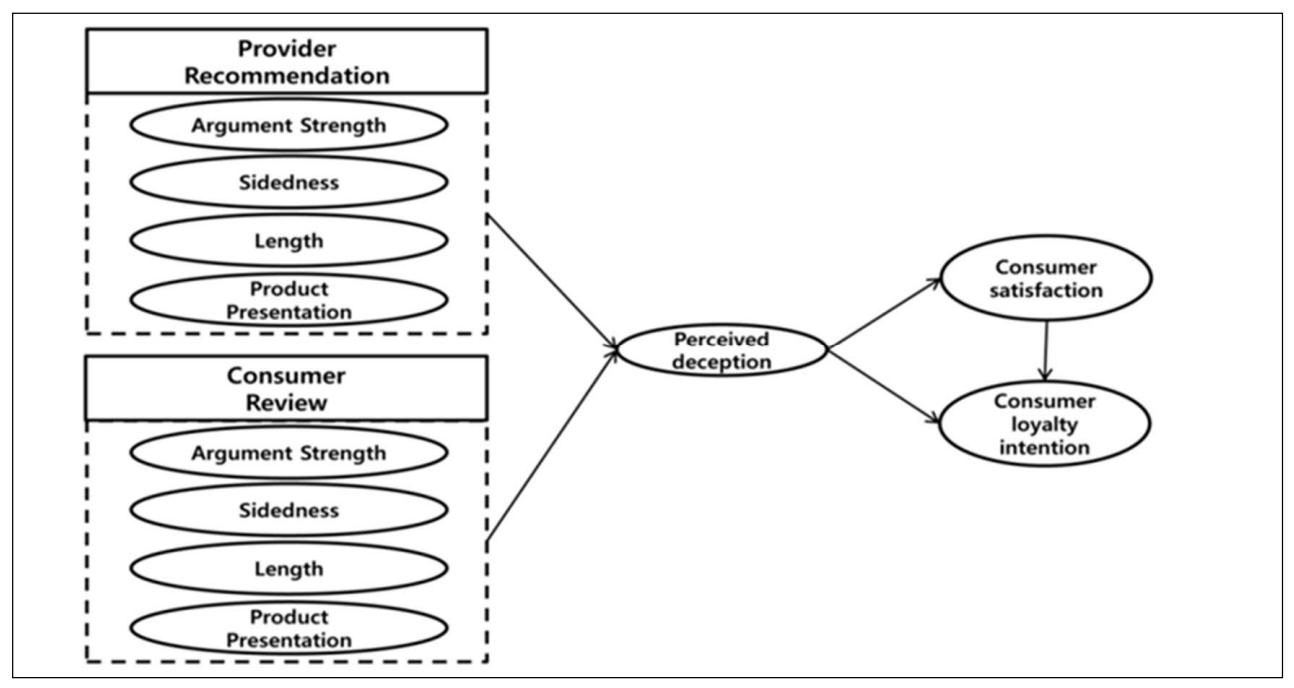

Figure 2 - Research Framework

\section{RESEARCH METHODOLOGY}

\subsection{Survey Instrument}

The attributes were summarized into multiple items and a survey instrument was created. This instrument asked respondents to investigate the extent to which they agreed/disagreed with these items in relation to their shopping experiences with curation commerce websites. Respondents rated each item on a scale of 1-5, where 5 represented "strongly agree" and 1 represented "strongly disagree." In addition, we collected demographic data from the respondents, including information on their experiences with a number of online purchases on the curation commerce website in the last six months, the product family (search products vs. experiential products) of their purchases, and the amount of money spent on curation commerce website purchases. The survey instrument was pilot tested with 5 doctoral candidate students and 15 others who had prior experience with the online curation commerce website. We also considered expert opinions. The experts consisted of the curation commerce website's CEO, manager, and technician. We shared our survey instruments with the experts. The items were revised based on their feedback. Following the revision, the survey was administered to a sample of 350 individuals who were prior users of the curation commerce website. As we wanted to gather data on consumer perceptions about the important characteristics of curation commerce websites, we eliminated the answers from individuals who lacked experience with curation commerce websites. Of the 350 individuals contacted, only 205 answers qualified for analysis. 
Table 1 - Survey Instrument Items

\begin{tabular}{|c|c|c|c|}
\hline Variables & Item & Content & Reference \\
\hline $\begin{array}{l}\text { Provider } \\
\text { Recommendation } \\
\text { Argument } \\
\text { Strength }\end{array}$ & $\begin{array}{l}\text { PAS1 } \\
\text { PAS2 } \\
\text { PAS3 }\end{array}$ & $\begin{array}{l}\text { Provider Recommendation Arguments are } \\
\text { convincing. } \\
\text { Provider Recommendation Arguments are } \\
\text { persuasive. } \\
\text { Provider Recommendation Arguments are strong. }\end{array}$ & \multirow[t]{4}{*}{$\begin{array}{l}\text { (Cheung, } \\
\text { et al., } \\
2009)\end{array}$} \\
\hline $\begin{array}{l}\text { Consumer } \\
\text { Review } \\
\text { Argument } \\
\text { Strength }\end{array}$ & $\begin{array}{l}\text { CAS1 } \\
\text { CAS2 } \\
\text { CAS3 }\end{array}$ & $\begin{array}{l}\text { Consumer Review Arguments are convincing. } \\
\text { Consumer Review Arguments are persuasive. } \\
\text { Consumer Review Arguments are strong. }\end{array}$ & \\
\hline $\begin{array}{l}\text { Provider } \\
\text { Recommendation } \\
\text { Sidedness }\end{array}$ & $\begin{array}{l}\text { PSD1 } \\
\text { PSD2 } \\
\text { PSD3 }\end{array}$ & $\begin{array}{l}\text { Provider Recommendation includes both pros and } \\
\text { cons of product/service. } \\
\text { Provider Recommendation includes only one-sided } \\
\text { comments (positive or negative). } \\
\text { Provider Recommendation explains both strong } \\
\text { points and weak points of the product/service as a } \\
\text { neutral position. }\end{array}$ & \\
\hline $\begin{array}{l}\text { Consumer } \\
\text { Review Sidedness }\end{array}$ & $\begin{array}{l}\text { CSD1 } \\
\text { CSD2 } \\
\text { CSD3 }\end{array}$ & $\begin{array}{l}\text { Consumer Review includes both pros and cons of the } \\
\text { product/service. } \\
\text { Consumer Review includes only one-sided } \\
\text { comments (positive or negative). } \\
\text { Consumer Review explains both strong points and } \\
\text { weak points of the product/service as a neutral } \\
\text { position. }\end{array}$ & \\
\hline $\begin{array}{l}\text { Provider } \\
\text { Recommendation } \\
\text { Length }\end{array}$ & $\begin{array}{l}\text { PL1 } \\
\text { PL2 } \\
\text { PL3 }\end{array}$ & $\begin{array}{l}\text { Provider Recommendation length is enough for } \\
\text { goods. } \\
\text { Provider Recommendation length is appropriate for } \\
\text { introducing goods. } \\
\text { Provider Recommendation length provides no } \\
\text { overflow/no deficient information about goods. }\end{array}$ & \multirow[t]{2}{*}{$\begin{array}{l}\text { (Baek, } \\
\text { Ahn and } \\
\text { Choi., } \\
\text { 2012) }\end{array}$} \\
\hline $\begin{array}{l}\text { Consumer } \\
\text { Review Length }\end{array}$ & $\begin{array}{l}\text { CL1 } \\
\text { CL2 } \\
\text { CL3 }\end{array}$ & $\begin{array}{l}\text { Consumer Review length is enough for the goods. } \\
\text { Consumer Review length is appropriate for } \\
\text { introducing goods. } \\
\text { Consumer Review length provides no overflow/no } \\
\text { deficient information about the goods. }\end{array}$ & \\
\hline $\begin{array}{l}\text { Provider } \\
\text { Recommendation } \\
\text { Product } \\
\text { Presentation }\end{array}$ & $\begin{array}{l}\text { PPP1 } \\
\text { PPP2 } \\
\text { PPP3 }\end{array}$ & $\begin{array}{l}\text { Provider Recommendation provides sufficient size of } \\
\text { visual cues. } \\
\text { Provider Recommendation provides high resolution } \\
\text { of visual cues. } \\
\text { Provider Recommendation provides various figures } \\
\text { taken from different angles of goods. }\end{array}$ & \multirow[t]{2}{*}{$\begin{array}{l}\text { (Lee and } \\
\text { Benbasat, } \\
\text { 2003) }\end{array}$} \\
\hline $\begin{array}{l}\text { Consumer } \\
\text { Review Product } \\
\text { Presentation }\end{array}$ & $\begin{array}{l}\text { CPP1 } \\
\text { CPP2 } \\
\text { CPP3 }\end{array}$ & $\begin{array}{l}\text { Consumer Review provides sufficient size of visual } \\
\text { cues. } \\
\text { Consumer Review provides high resolution of visual } \\
\text { cues. } \\
\text { Consumer Review provides various figures taken } \\
\text { from different angles of the goods. }\end{array}$ & \\
\hline
\end{tabular}




\begin{tabular}{|l|l|l|l|}
\hline Variables & Item & Content & Reference \\
\hline $\begin{array}{l}\text { Perceived } \\
\text { deception }\end{array}$ & PD1 & $\begin{array}{l}\text { The site exaggerates the benefits and characteristics } \\
\text { of its offerings. } \\
\text { The site uses misleading tactics to convince } \\
\text { consumers to buy its products. } \\
\text { The site is not entirely truthful about its offerings. } \\
\text { The site attempts to persuade you to buy things that } \\
\text { you do not need. }\end{array}$ & $\begin{array}{l}\text { (Román, } \\
\text { 2010) }\end{array}$ \\
\hline $\begin{array}{l}\text { PDonsumer } \\
\text { satisfaction }\end{array}$ & CS1 & $\begin{array}{l}\text { I am satisfied with my decision to purchase from this } \\
\text { site. } \\
\text { My choice to purchase from this site was a wise one. } \\
\text { I am happy I made my purchase at this website. }\end{array}$ & \\
\cline { 1 - 3 } $\begin{array}{l}\text { Consumer loyalty } \\
\text { intention }\end{array}$ & CLI1 & $\begin{array}{l}\text { I plan to do business with this website in the future. } \\
\text { I would recommend the website to someone who } \\
\text { seeks my advice. } \\
\text { I will advise friends and relatives to try this website } \\
\text { at least once. }\end{array}$ & \\
\hline
\end{tabular}

\subsection{Sample}

In August 2015, we conducted a web-based survey and a paper-based survey. Sample of this research is collected on 3 major curation commerce websites in South Korea. 3curation commerce websites have similar infrastructure and all of them has enough quantity of PR and CR. The characteristics of the respondents are represented as follows. We had a diverse sample of respondents with approximately $50 \%$ between the ages of 20 and 29 and approximately $30 \%$ between the ages of 30 and 39. More than 97\% had a purchase experience in the past six months. Moreover, $94 \%$ of respondents spent more than 10,000 won on the curation commerce website during one transaction. Additionally, more than $70 \%$ primarily used the curation commerce website for experiential products. The profiles indicate that they were heterogeneous and had considerable curation commerce experience. We estimated the level of non-response bias by comparing early and late respondents. According to the method proposed by a prior study (Armstrong and Overton, 1977), the t-tests for each case showed that the early and late respondents had no significant differences in terms of their gender, age, and occupation.

\section{DATA ANLLYSIS AND RESULTS}

Data analysis was conducted using the structural equation modeling technique of partial least squares (PLS) with SmartPLS 2.0. PLS is primarily intended for causal-predictive analysis in situations of high complexity. Additionally, regarding the sample, PLS is not as restrictive as multivariate normal data distributions, and scales may be ordinal. We first conducted the validity of the measurement instrument and then tested the hypotheses. 


\subsection{Measurement Model}

To verify the instrument conceptually, seven innovation management researchers, two curation commerce website managers, and two curation commerce curators examined the measurement items and reviewed their face validity. We further inspected the constructs for convergent and discriminant validity. Convergent validity can be assessed using the following criteria: (1) the factor loadings of survey items should be significant and exceed 0.7, (2) the composite reliability (CR) and Cronbach's alpha should exceed 0.7, and (3) the average variance extracted (AVE) of the constructs should exceed 0.5 (Fornell and Larcker, 1981; Gefen, Straub and Boudreau, 2000). As shown in Tab. 3, the standardized path loadings of all survey items are significant ( $t$ values $>1.96)$ and larger than 0.7. The CR and Cronbach's alpha for all constructs exceeded 0.7 and the AVE for each construct was larger than 0.5. Therefore, the measures show good convergent validity.

Table 3 - Convergent Validity

\begin{tabular}{|l|l|l|c|c|}
\hline Variables & Factor Loadings & AVE & CR & Cronbach's $\boldsymbol{\alpha}$ \\
\hline PAS & $0.725,0.887,0.879$ & 0.695 & 0.871 & 0.780 \\
\hline PSD & $0.975,0.763,0.973$ & 0.826 & 0.934 & 0.901 \\
\hline CLI & $0.928,0.874,0.895$ & 0.808 & 0.927 & 0.881 \\
\hline PPP & $0.873,0.884,0.885$ & 0.776 & 0.912 & 0.865 \\
\hline PL & $0.801,0.972,0.940$ & 0.823 & 0.923 & 0.897 \\
\hline CAS & $0.819,0.803,0.869$ & 0.690 & 0.869 & 0.814 \\
\hline CSD & $0.897,0.918,0.859$ & 0.795 & 0.920 & 0.874 \\
\hline CPP & $0.827,0.826,0.971$ & 0.769 & 0.909 & 0.944 \\
\hline CL & $0.757,0.955,0.960$ & 0.802 & 0.923 & 0.880 \\
\hline PD & $0.874,0.851,0.749$ & 0.683 & 0.866 & 0.769 \\
\hline CS & $0.932,0.958,0.949$ & 0.895 & 0.962 & 0.941 \\
\hline
\end{tabular}

Note: PAS: Provider Recommendation Argument Strength, PSD: Provider Recommendation Sidedness, CLI: Consumer Loyalty Intention, PPP: Provider Recommendation Product Presentation, PL: Provider Recommendation Length, CAS: Consumer Review Argument Strength, CSD: Consumer Review Sidedness, CPP: Consumer Review Product Presentation, CL: Consumer Review Length, PD: Perceived Deception, CS: Consumer Satisfaction.

Discriminant validity is estimated using the guidance suggested by Fornell and Larcker (Fornell and Larcker, 1981), in which the square root of AVE for each construct should exceed the correlation between it and any other constructs. Tab. 4 represents the correlation matrix, with the correlations among the constructs and the square root of AVE shown diagonally. The diagonal values exceed the interconstruct correlations; hence, the result of the test of discriminant validity is acceptable. 
Table 4 - Discriminant Validity

\begin{tabular}{|c|c|c|c|c|c|c|c|c|c|c|c|}
\hline & PAS & PSD & CLI & PPP & PL & CAS & CSD & CPP & CL & PD & CS \\
\hline PAS & 0.83 & & & & & & & & & & \\
\hline PSD & 0.15 & 0.90 & & & & & & & & & \\
\hline CLI & 0.36 & 0.16 & 0.89 & & & & & & & & \\
\hline PPP & 0.41 & 0.16 & 0.50 & 0.88 & & & & & & & \\
\hline PL & 0.29 & 0.06 & 0.35 & 0.45 & 0.91 & & & & & & \\
\hline CAS & -0.13 & -0.11 & 0.07 & -0.02 & -0.05 & 0.83 & & & & & \\
\hline CSD & 0.11 & -0.08 & 0.25 & 0.33 & 0.11 & 0.01 & 0.89 & & & & \\
\hline CPP & 0.04 & 0.18 & 0.23 & 0.15 & 0.05 & 0.30 & 0.17 & 0.88 & & & \\
\hline CL & 0.02 & 0.09 & 0.08 & 0.01 & 0.07 & 0.43 & 0.09 & 0.41 & 0.89 & & \\
\hline PD & -0.17 & 0.04 & -0.32 & -0.28 & -0.20 & 0.20 & -0.21 & -0.04 & 0.19 & 0.83 & \\
\hline CS & 0.39 & 0.14 & 0.49 & 0.51 & 0.36 & 0.05 & 0.32 & 0.22 & 0.05 & -0.37 & 0.96 \\
\hline
\end{tabular}

Note: PAS: Provider Recommendation Argument Strength, PSD: Provider Recommendation Sidedness, CLI: Consumer Loyalty Intention, PPP: Provider Recommendation Product Presentation, PL: Provider Recommendation Length, CAS: Consumer Review Argument Strength, CSD: Consumer Review Sidedness, CPP: Consumer Review Product Presentation, CL: Consumer Review Length, PD: Perceived Deception, CS: Consumer Satisfaction.

After testing the measurement model, we checked for possible common method variance (CMV). Harman's single-factor test examined whether a single factor accounted for a majority of the variance in the data (Podsakoff, et al., 2003). Principal component analysis with eigenvalues larger than one was used to extract the factors. The CMV analysis result showed that CMV was not a serious problem in this study.

\subsection{Structural Model}

We tested the hypotheses using PLS. Fig. 3 represents the results of the PLS structural model assessment including the overall explanatory power and estimated path coefficients. Tests of the significance of all paths were performed using the bootstrap resampling procedure.

CR argument $(\beta=-0.214), C R$ sidedness $(\beta=-0.115)$ and PR product presentation $(\beta=-0.231)$ have significant influence on perceived deception at $p$ $<0.01, \mathrm{p}<0.01$ and $\mathrm{p}<0.01$. Thus, H1b, H2b and H3a are supported. Perceived deception $(\beta=-0.369)$ has a significant effect on consumer satisfaction, and consumer satisfaction $(\beta=0.787)$ has a significant effect on consumer loyalty intentions at $\mathrm{p}<0.01$ and $\mathrm{p}<0.01$. Thus, $\mathrm{H} 5$ and $\mathrm{H} 7$ are supported. However, the path coefficients of PR argument strength, PR sidedness and CR product presentation showed insignificance to perceived deception and the path coefficient of perceived deception to consumer loyalty intentions (H1a, H2a, 
$\mathrm{H} 3 \mathrm{a}, \mathrm{H} 4 \mathrm{~b}$, and H6). The explanatory power $\left(\mathrm{R}^{2}\right)$ for perceived deception $(0.15)$, consumer satisfaction (0.14), and consumer loyalty intentions (0.64) are larger than the accepted threshold of 0.10 (Falk and Miller, 1992).

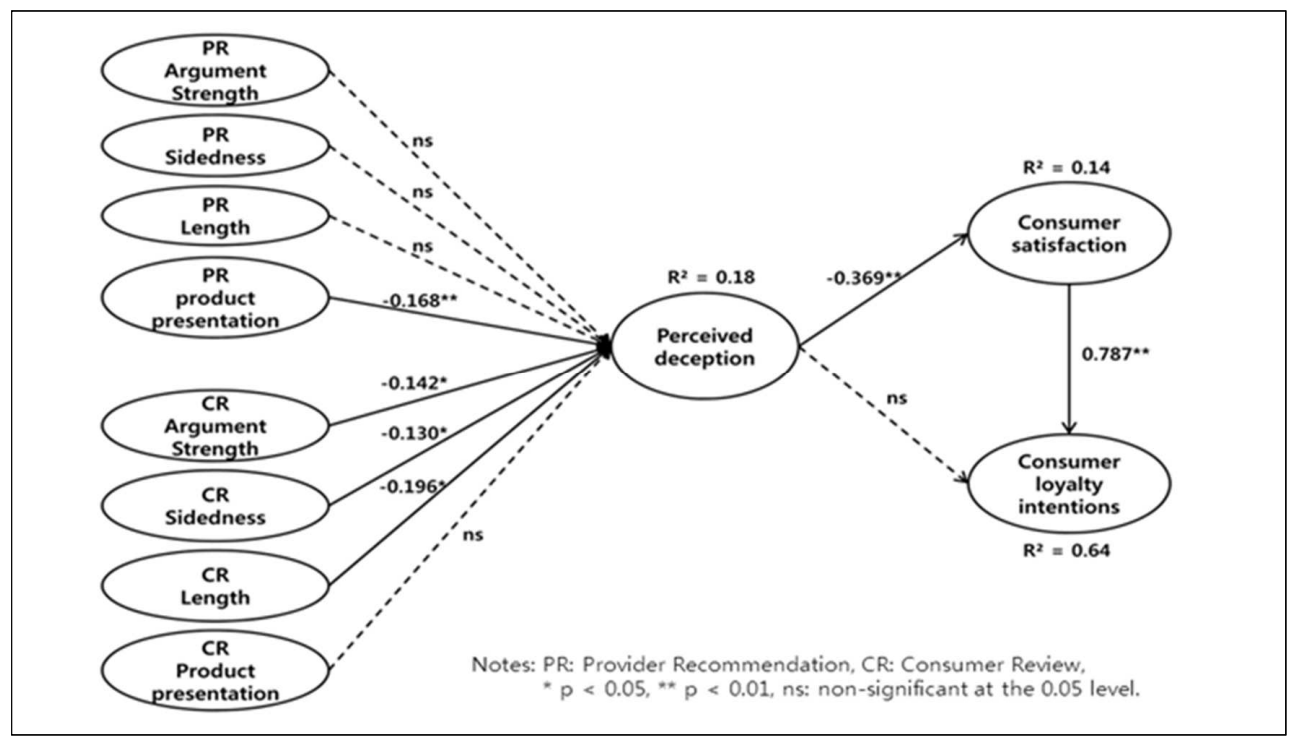

Figure 3 - Results of the Hypotheses Tests

\section{CONCLUSION}

\subsection{Discussion of the Findings}

Our results contain several important findings. The first finding is that perceived deception acts as a key indicator of consumer satisfaction and consumer loyalty intentions. Statistically supported independent variables influence consumer satisfaction and consumer loyalty intentions through perceived deception. Additionally, in contrast to our expectations, perceived deception had no direct influence on consumer loyalty intentions when estimating the relationship between satisfaction and loyalty. Interestingly, a post-hoc analysis revealed that perceived deception had an important and significant effect on consumer loyalty intentions when the path from satisfaction to loyalty was not estimated. Perceived deception has significant influence on consumer satisfaction $(\beta=$ $0.371)$ and consumer loyalty intentions $(\beta=-0.329)$ at $p<0.01$ and $p<0.01$. The explanatory power $\left(\mathrm{R}^{2}\right)$ for perceived deception $(0.15)$, Consumer satisfaction (0.14) and consumer loyalty intentions (0.11) are larger than the accepted threshold of 0.10 (Falk and Miller, 1992). In conclusion, this finding highlights the concept that the key mediating role of consumer satisfaction in perceived deception is the consumer loyalty intentions link. Additionally, the theory of reasoned action (TRA) explains that attitude (consumer satisfaction) is essential to raising consumer behavioral intentions (consumer loyalty intentions). These 
results are also consistent with the prior work of Ingram et al. and Román (Ingram, Skinner and Taylor, 2005; Román, 2010).

Next, among the PR characteristics, only PR product presentation plays a significant role regarding consumer loyalty intentions. This effect can be explained by the notion that consumers tend to believe that PR product presentations cannot be manufactured easily. However, the strength of the PR argument has no effect on consumer loyalty intentions. One interviewee, who is a practical curation commerce website manager, explained the concept as follows. In the online shopping environment, the possibility of exaggeration through PR argument strength by the provider/curator always exists. Therefore, consumers can doubt the trustworthiness and tend not to take into account argument strength.

In addition, our findings indicate that $\mathrm{CR}$ argument strength influences consumer loyalty intentions through perceived deception and consumer satisfaction. This finding is similar to that of previous research that found that CR argument strength directly influences the perceived credibility in a consumer forum website (Cheung, et al., 2009). This finding may be interpreted to indicate that readers do not blindly follow CR. Consumers believe in reviews that are supported by valid and strong arguments. Additionally, consumers in curation commerce websites do not feel the deception when they refer to two-sided reviews. One curation commerce website manager agreed with this finding. He mentioned that consumers are likely to think that having CR that are too positive are manufactured by the provider and CR that are too negative are fabricated by other competitor firms. Therefore, maintaining the balance of sidedness to affect other consumers is important. This finding contradicts prior similar research (Cheung, et al., 2009).

\subsection{Practical Implications}

This study presents a picture that describes the effects of PR and CR characteristics on curation website loyalty intentions. We derive a number of practical implications and provide them to practitioners and administrators of curation commerce websites with strong instructional insights.

First, to enhance the competitiveness of a website, a loyalty provider should offer adequate product presentations of good quality and enough quantity of presentation to its consumers. The provider should upload not only images taken from various angles but also more detailed presentations. For example, in the case of clothing, the provider needs to offer photographs of the clothing taken from various angles and of men with different body shapes wearing the clothing in different lighting. Such photographs can be helpful to consumers who have not seen the actual clothing and help in decreasing the deception of the curation commerce website.

Second, the website manager cannot directly manage CR. However, they are able to manage reviews in various indirect ways. A manager should fix spelling errors 
and typographical errors, and delete the content in other product advertisements. According to our research findings, consumers on a curation commerce website do not blindly follow other consumers' reviews but are concerned about CRs' overall quality. Therefore, a website manager who pays attention to managing CRs can be useful in strengthening the consumer loyalty intentions of the website.

Third, our research findings highlight the concept that CR sidedness also needs to be managed. In general, we expect that only CRs with a positive aspect would have a positive effect on purchase intention and website consumer loyalty intention. However, according to our findings, we discovered that consumers' reference to a review that contains both positive and negative contents about a product is more effective for a website's consumer loyalty intention. For this reason, a website manager should lead consumers to write reviews with both positive and negative content and do not be afraid of negative opinion about their product. For example, the manager could notify consumers that writing both positive and negative opinions is good for the product. Such a method can result in two-sided reviews and indicate to consumers the website's willingness to consider weaknesses in its products.

\subsection{Theoretical Implications}

This study makes several important scientific contributions.

First, in the marketing context, previous traditional research found strong evidence for a positive effect of consumer satisfaction on consumer behavioral intentions. This study is one of the few to clarify the strong and positive effect from consumer satisfaction on consumer loyalty intentions in the online business context (Fassnacht and Køse, 2007; Román, 2010). Additionally, our findings extend the prior theory of reasoned action (Fishbein and Ajzen, 1975), which theorized that consumer behavioral intentions (e.g., consumer loyalty intentions) are determined by attitude (e.g., consumer satisfaction). In particular, we verified this relationship to curation commerce, which is the newest type of e-commerce.

Second, From this study, we clarified the negative perception of the consumer (deception) as a mediating factor. This attempt extends the analysis related to consumer psychology, consumer perception, and consumer behavior. Additionally, several prior studies discovered an influential provision of PR and $\mathrm{CR}$ on the usefulness and social presence of an online shopping website. To obtain some more tangible findings, we verified the effects of PR and CR stimuli. These findings reflect consumers real purchase behavior in a curation commerce website.

Third, because curation commerce is a relatively new concept, academic research on curation commerce is insufficient. Thus, the conception of curation commerce is unclear. Our research attempts to apply a mixed method to define and obtain insights into curation commerce and to enrich the existing findings. This attempt could form the basis for research on curation commerce. 


\section{REFERENCES}

Adams, J.S., 1963. Towards an understanding of inequity. The Journal of Abnormal and Social Psychology, 67(5), pp.422-436.

Aditya, R.N., 2001. The psychology of deception in marketing: A conceptual framework for research and practice. Psychology and Marketing, 18(7), pp.735761.

Allen, M., 1993. Determining the persuasiveness of message sidedness: A prudent note about utilizing research summaries. Western Journal of Communication, 57(1), pp.98-103.

Armstrong, J.S. and Overton, T.S., 1977. Estimating nonresponse bias in mail surveys. Journal of marketing research, 14(3), pp.396-402.

Baek, H., Ahn, J. and Choi, Y., 2012. Helpfulness of Online Consumer Reviews: Readers' Objectives and Review Cues. International Journal of Electronic Commerce, 17(2), pp.99-126.

Bagozzi, R.P., 1986. Principles Of Marketing Management. Chicago: Science Research Associates Chicago.

Baker, J., Grewal, D. and Parasuraman, A., 1994. The influence of store environment on quality inferences and store image. Journal of the academy of marketing science, 22(4), pp.328-339.

Belch, G.E., 1981. An examination of comparative and noncomparative television commercials: The effects of claim variation and repetition on cognitive response and message acceptance. Journal of Marketing Research, 18(3), pp.333-349.

Brin, S., 1998. The anatomy of a large-scale hypertextual Web search engine 1. Computer Networks, 30(1-7), pp.107-117.

Bunker, A.M., 1994. Credibility and argument strength: persuasive effects when processing ability is impaired. MI, East Lansing: Michigan State University.

Cacioppo, J.T., Petty, R.E. and Morris, K.J., 1983. Effects of need for cognition on message evaluation, recall, and persuasion. Journal of personality and social psychology, 45(4), pp.805-818.

Chang, H.H. and Chen, S.W., 2008. The impact of online store environment cues on purchase intention: Trust and perceived risk as a mediator. Online Information Review, 32(6), pp.818-841.

Cheung, M., Luo, C., Sia, C. and Chen, H., 2009. Credibility of electronic wordof-mouth: Informational and normative determinants of on-line consumer recommendations. International Journal of Electronic Commerce, 13(4), pp.938. 
Cho, J.-K. 1995. An examination of the attitudinal effects of comparative vs. noncomparative advertising and their causal paths in the context of message sidedness and product involvement. CT, Mansfield: University of Connecticut.

Dorčák, P., Štrach, P. and Pollák, F., 2015. Analytical View Of The Perception Of Selected Innovative Approaches In Marketing Communications. Quality Innovation Prosperity, 19(1), pp.74-84.

Falk, R.F. and Miller, N.B., 1992. A primer for soft modeling. OH, Akron: University of Akron Press.

Fassnacht, M. and Køse, I., 2007. Consequences of Web-based service quality: Uncovering a multi-faceted chain of effects. Journal of Interactive marketing, 21(3), pp.35-54.

Fishbein, M. and Ajzen, I. 1975. Belief, attitude, intention and behavior: An introduction to theory and research. Journal of Business Ventruing, 5, pp.177189.

Fornell, C. and Larcker, D.F., 1981. Evaluating structural equation models with unobservable variables and measurement error. Journal of marketing research, 18(1), pp.39-50.

Gefen, D., Straub, D. and Boudreau, M.-C., 2000. Structural equation modeling and regression: Guidelines for research practice. Communications of the association for information systems, 4(7), pp.1-78.

Gogan, J.L., 1996. The Web's impact on selling techniques: Historical perspective and early observations. International Journal of Electronic Commerce, 1(2), pp.89-108.

Ho, J., 1997. Evaluating the World Wide Web: A global study of commercial sites. Journal of Computer-Mediated Communication, 3(1), pp.0-0.

Horváth, M. and Michalková, A., 2012. Monitoring Customer Satisfaction in Service Industry: A Cluster Analysis Approach. Quality Innovation Prosperity, 16(1), pp.49-54.

Huppertz, J.W., Arenson, S.J. and Evans, R.H., 1978. An application of equity theory to buyer-seller exchange situations. Journal of marketing research, 15(2), pp.250-260.

Ingram, R., Skinner, S.J. and Taylor, V.A., 2005. 'Consumers' evaluation of unethical marketing behaviors: The role of customer commitment. Journal of Business Ethics, 62(3), pp.237-252.

Klein, L.R., 1998. Evaluating The Potential Of Interactive Media Through A New lens: Search versus experience goods. Journal of business research, 41(3), pp.195-203. 
Lee, W. and Benbasat, I., 2003. Designing an electronic commerce interface: attention and product memory as elicited by web design. Electronic Commerce Research and Applications, 2(3), pp.240-253.

Liang, T.P. and Turban, E., 2011. Introduction to the special issue social commerce: A research framework for social commerce. International Journal of Electronic Commerce, 16(2), pp.5-13.

Lynch Jr, J.G. and Ariely, D., 2000. Wine online: Search costs affect competition on price, quality, and distribution. Marketing Science, 19(1), pp.83-103.

Morris, M.E. and Hinrichs, R.J., 1996. Web page design: a different multimedia, UK, New Jersey: Prentice-Hall, Inc.

Nabi, R.L. and Hendriks, A., 2003. The persuasive effect of host and audience reaction shots in television talk shows. Journal of Communication, 53(3), pp.527-543.

Oliver, R.L. and Desarbo, W.S., 1988. Response determinants in satisfaction judgments. Journal of consumer research, 14(4), pp.495-507.

Park, J., Lennon, S.J. and Stoel, L., 2005. On-line product presentation: Effects on mood, perceived risk, and purchase intention. Psychology \& Marketing, 22(9), pp.695-719.

Podsakoff, P.M., Mackenzie, S.B., Lee, J.-Y. and Podsakoff, N.P., 2003. Common method biases in behavioral research: a critical review of the literature and recommended remedies. Journal of applied psychology, 88(5), pp.879.

Ramïrez, M.L., 2011. Opinion: Whose role is it anyway?: A library practitioner's appraisal of the digital data deluge. Bulletin of the American Society for Information Science and Technology, 37(5), pp.21-23.

Roman, S., 2007. The ethics of online retailing: A scale development and validation from the consumers' perspective. Journal of Business Ethics, 72(2), pp.131-148.

Román, S., 2010. Relational consequences of perceived deception in online shopping: the moderating roles of type of product, consumer's attitude toward the internet and consumer's demographics. Journal of Business Ethics, 95(3), pp.373-391.

Romãn, S. and Ruiz, S., 2005. Relationship outcomes of perceived ethical sales behavior: The customer's perspective. Journal of Business Research, 58(4), pp.439-445.

Sherman, E., Mathur, A. and Smith, R.B., 1997. Store environment and consumer purchase behavior: mediating role of consumer emotions. Psychology \& Marketing, 14(4), pp.361-378.

Smith, R.E. and Hunt, S.D., 1978. Attributional processes and effects in promotional situations. Journal of Consumer Research, 5(3), pp.149-158. 
Swinyard, W.R., 1993. The effects of mood, involvement, and quality of store experience on shopping intentions. Journal of Consumer Research, 20(2), pp.271-280.

Tan, W.C., 2007. Provenance in Databases: Past, Current, and Future. IEEE Data Eng. Bull., 30(4), pp.3-12.

Then, N.K. and Delong, M.R., 1999. Apparel shopping on the web. Journal of Family and Consumer Sciences, 91(3), pp.65-68.

Vykydal, D., Halfarová, P. and Nenadál, J., 2013. Customer Loyalty Measurement at Czech Organizations. Quality Innovation Prosperity, 17(1), pp.28-38.

Whalen, J., Pitts, R.E. and Wong, J.K., 1991. Exploring the structure of ethical attributions as a component of the consumer decision model: The vicarious versus personal perspective. Journal of Business Ethics, 10(4), pp.285-293.

\section{ABOUT AUTHORS}

Sunghee Park, Ph.D. Candidate, Department of Convergence Technology Management Engineering, Yonsei University, Republic of Korea, e-mail: ifyoutry@naver.com.

Jaehyeon Jun, Ph.D. Candidate, Department of Industrial Engineering, Yonsei University, Republic of Korea, e-mail: theojay@yonsei.ac.kr.

Heejun Park, Corresponding Author, Professor, Department of Industrial Engineering, Yonsei University, Republic of Korea, e-mail: h.park@yonsei.ac.kr, Telephone: +82 22123 5717, Fax: +82 23647807 . 